
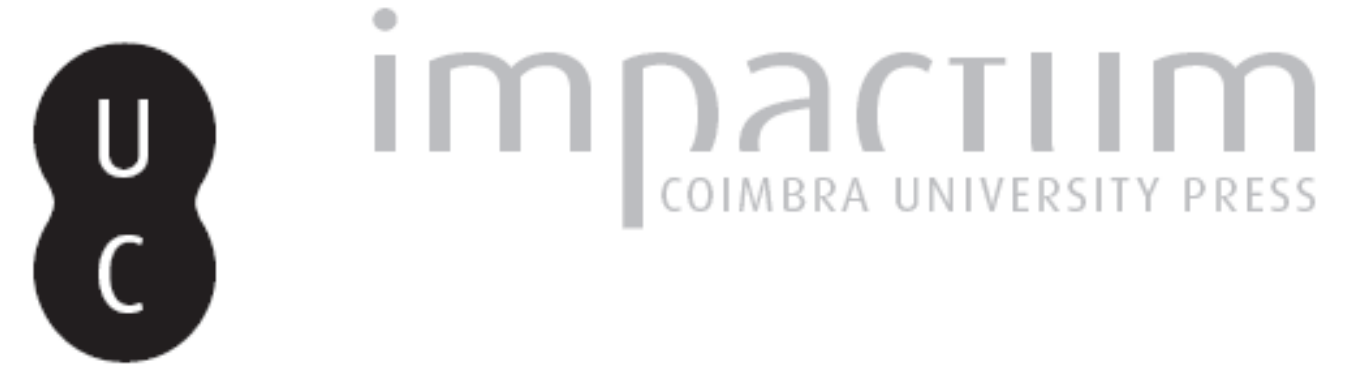

\title{
Os templos das musas: política cultural e cultura museológica na Coimbra republicana (1911-1926)
}

\author{
Autor(es): $\quad$ Pacheco, Milton Pedro Dias
}

Publicado por: Faculdade de Letras da Universidade de Coimbra

URL persistente:

URI:http://hdl.handle.net/10316.2/32462

DOI:

DOI:http://dx.doi.org/10.14195/0870-4112_9_11

Accessed : $\quad$ 26-Apr-2023 11:00:43

A navegação consulta e descarregamento dos títulos inseridos nas Bibliotecas Digitais UC Digitalis, UC Pombalina e UC Impactum, pressupõem a aceitação plena e sem reservas dos Termos e Condições de Uso destas Bibliotecas Digitais, disponíveis em https://digitalis.uc.pt/pt-pt/termos.

Conforme exposto nos referidos Termos e Condições de Uso, o descarregamento de títulos de acesso restrito requer uma licença válida de autorização devendo o utilizador aceder ao(s) documento(s) a partir de um endereço de IP da instituição detentora da supramencionada licença.

Ao utilizador é apenas permitido o descarregamento para uso pessoal, pelo que o emprego do(s) título(s) descarregado(s) para outro fim, designadamente comercial, carece de autorização do respetivo autor ou editor da obra.

Na medida em que todas as obras da UC Digitalis se encontram protegidas pelo Código do Direito de Autor e Direitos Conexos e demais legislação aplicável, toda a cópia, parcial ou total, deste documento, nos casos em que é legalmente admitida, deverá conter ou fazer-se acompanhar por este aviso.

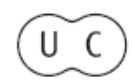



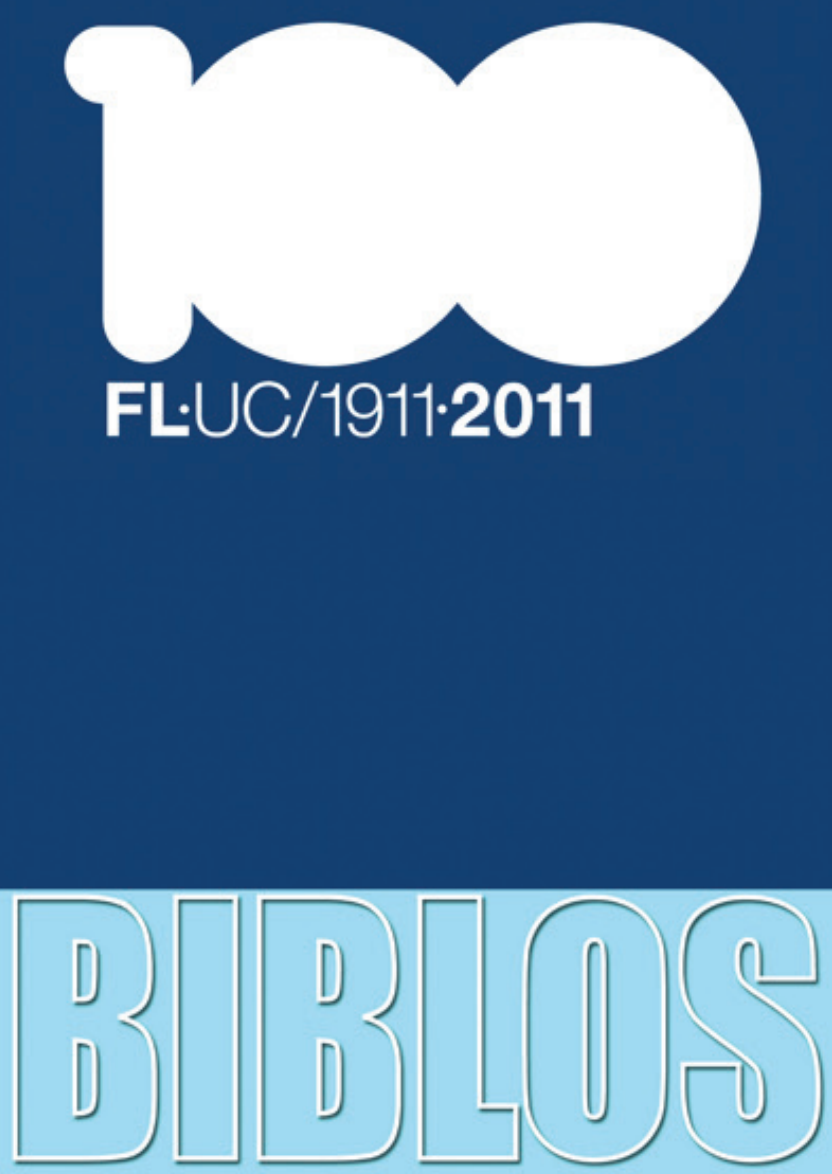

REVISTA DA FACULDADE DE LETRAS UNIVERSIDADE DE COIMBRA 


\author{
Milton Pedro Dias Pacheco \\ Departamento dos Bens Culturais da Diocese de Coimbra \\ Investigador a preparar o doutoramento em História da Arte
}

\title{
OS TEMPLOS DAS MUSAS: \\ POLÍTICA CULTURAL E CULTURA MUSEOLÓGICA \\ NA COIMBRA REPUBLICANA (1911-1926)
}

\section{Resumo}

No seguimento da implantação da I República em Portugal foi confiada a um escol de eruditos e dirigentes estadistas, com fortes ligações à Universidade de Coimbra, a missão de reformular a política cultural nacional e projectar uma nova rede de museus nos principais centros urbanos do país.

Assim, também em Coimbra, após a nacionalização de um conjunto de bens patrimoniais pertencentes ou ligados à Igreja Católica foram estabelecidos os mecanismos fundamentais para a reorganização e concepção de novas instituições museológicas para disponibilizar ao grande público o património arquitectónico e o espólio artístico mais representativo da história Pátria. Procurando enaltecer os grandes valores ideológicos republicanos, alguns dos monumentos citadinos eram então destinados ao serviço da educação e instrução de todas as classes sociais, como iremos demonstrar.

Palavras-Chave: Republicanismo, Nacionalização patrimonial, Política museológica, Democratização cultural, Museus conimbricenses.

\begin{abstract}
Following the establishment of the $1^{\text {st }}$ Republic in Portugal, a mission was entrusted to an elite group of scholars and statesmen leaders, with strong connections to the University of Coimbra, to reform the national cultural policy and design a new network of museums in major urban centers.

Therefore, in Coimbra, after the nationalization of a set of patrimonial assets belonging or connected to the Catholic Church, the fundamental mechanisms for the reorganization and development of new museum institutions with the purpose of providing to the public the most representative architectural heritage and artistic estate of Portuguese History were established. As we will demonstrate, in order to enhance the great ideological republican's values, some of the city monuments were at the service of the education and instruction of all social classes.
\end{abstract}

Keywords: Republicanism, Asset nationalization, Museum politics, Cultural democratization, Coimbra's museums. 
As sucessivas convulsões políticas e sociais que dominaram os diferentes quadrantes da sociedade portuguesa entre os finais do século XIX e os primeiros anos do século XX culminariam com a proclamação da República no dia 5 de Outubro de 1910. Com a instauração do novo regime fora deposta uma das monarquias mais antigas da Europa e enfraquecido aquele que era considerado um dos seus principais sustentáculos, a Igreja Católica.

Perante a necessidade de consolidar a jovem República, o Governo Provisório avançou rapidamente com a homologação de inúmeros decretos e portarias com força de Lei que levariam à laicização da sociedade e à nacionalização de um vasto conjunto patrimonial das instituições vinculadas à Monarquia.

Núcleo histórico por excelência da Nação, a cidade de Coimbra, berço de monarcas, sede de bispos e assento de escolares, iria servir de espaço laboratorial para muitas das políticas e práticas culturais ensaiadas por um escol de eruditos e dirigentes estadistas republicanos com fortes ligações à mais antiga Academia do país.

A expressão máxima da perseguição política encetada contra a provinciana e beata Universidade de Coimbra, alvo de severas críticas ao longo de toda a centúria de Oitocentos pelo seu fundamentalismo dogmático, é testemunhada, de facto, com a publicação de um rol de diplomas asfixiantes logo nos meses imediatos à implantação da República.

Homologados os decretos-lei de 18 e 23 de Outubro de 1910, a instituição universitária assistia passivamente à abolição dos actos cerimoniais e juramentos religiosos durante a atribuição de graus académicos previstos nos Estatutos, à interdição dos préstitos processionais e participação nas principais festividades do Calendário Litúrgico, que se confundiam com as da própria cidade, e à proibição de matrículas no primeiro ano da Faculdade de Teologia. Suprimida não por ser hostil ou adversa à República mas por ser prescindível à sociedade "como que um orgão sem função" -, aquela acabaria por dar origem à actual Faculdade de Letras, que este ano celebra os cem anos de existência. Com o diploma de 14 de Novembro era extinta a cadeira de Direito Canónico na Faculdade de Direito, e no ano seguinte,

${ }^{1}$ A Faculdade de Letras da Universidade de Coimbra ao País, Coimbra, Tip. França Amado, 1919, p. 15. 
em 22 de Março, Coimbra perdia o monopólio do ensino superior com a fundação das universidades de Lisboa e do Porto $^{2}$.

Disfarçando os verdadeiros intentos, o Governo Provisório, por decreto de 21 de Janeiro de 1911, determinou o encerramento e a extinção do culto na capela de São Miguel, o multisecular templo integrado no Paço das Escolas ${ }^{3}$ afecto à Faculdade de Teologia desde 1902, que servia de palco às principais manifestações corporativas religiosas da Academia conimbricense ${ }^{4}$.

Tendo em conta que "as sciencias entraram definitivamente no periodo da sua emancipação de todos os elementos estranhos á razão [...] e atendendo tambem a que estão destinadas a imperar pelo poder incruento e irreductivel da verdade demonstrada, a qual acabará com as dissidencias das escolas dogmaticas que teem até hoje dividido os individuos e os povos", como era salientado no decreto de 21 de Janeiro, estabelecia-se que a capela universitária fosse convertida em museu de arte sacra. Sob a supervisão do director do Arquivo da Universidade de Coimbra (art. $4^{\circ}$ ), o museu teria como principal acervo as alfaias litúrgicas, livros sagrados e paramentos sacerdotais, bem como um importante conjunto de pintura e imaginária devocional (art. 3..$\left.^{\circ}\right)^{5}$.

${ }^{2}$ Fernando CATROGA, "O laicismo e a questão religiosa em Portugal (1865-1911)”, Análise Social, vol. 100, 1988, Lisboa, pp. 250 a 253; e; Afonso COSTA, Discursos parlamentares (1911-1914), António de Oliveira MARQUES, (Compilação, prefácio e notas), Amadora, Livraria Bertrand, 1976, p. 480.

${ }^{3}$ De modo a legitimar a acção cometida seria ainda despachado pelo mesmo diploma de 21 de Janeiro, embora desnecessariamente, a sua classificação como Monumento Nacional, quando na verdade já estava classificado desde 16 de Junho de 1910, integrado no complexo universitário do Paço das Escolas.

${ }^{4}$ Fora Sidónio Pais, à data vice-reitor da Universidade, que no seguimento do despacho governamental procedera ao encerramento da capela. Manuel Augusto Rodrigues, "Introdução", António de VASCONCELOS, Real Capela da Universidade, Coimbra, Arquivo da Universidade de Coimbra/Livraria Minerva, 1990, p. VII, pp. 36 e 272.

${ }_{5}$ No entanto, o projecto de transformação museológica da capela universitária ficaria estagnado até 1934, aquando da homologação decreto-lei 23.625 de 3 de Março, abrindo as instalações somente em 8 de Dezembro de 1972. O culto seria reactivado em 25 de Outubro de 1936. "Decreto com força de lei de 21 de Janeiro de 1911", Diário do Governo, n. . 18, 23 de Janeiro de 1911, apresentado por António de VASCONCELOS, Real Capela da Universidade, [...], pp. 271 a 277. 
Mas se esta medida, supostamente o reflexo da renovadora política cultural do regime republicano, havia beliscado o orgulho do episcopado português, a homologação da Lei da Separação do Estado das Igrejas, diploma pelo qual seria espoliado da maior parte do seu património, deixá-lo-ia prostrado perante o ministro da Justiça Afonso Costa (1871-1937). Preparado num ambiente anticlericalista, o decreto com força de Lei confirmado em 20 de Abril de 1911, determinaria que a confissão Católica Apostólica Romana deixaria de ser a religião oficial do Estado português (art. 2. $\left.{ }^{\circ}\right)^{6}$. Aliás, segundo as previsões de Afonso Costa, o Catolicismo em Portugal deveria ficar extinto dentro de duas ou três gerações .

Apesar dos protestos subscritos publicamente pelos vários prelados, o primeiro a 6 de Maio e o segundo a 5 de Dezembro de 1911, nos quais questionavam a legitimidade do Estado em privar a Igreja do direito à propriedade e o acusavam de seguir uma política doutrinal colectivista e socialista ${ }^{8}$, os republicanos avançariam com o processo de apropriação do património construído, os edifícios para o culto e habitação dos vários ministros, nomeadamente os palácios episcopais ${ }^{9}$. Esta deliberação fora considerada a consequência inevitável da evolução da "sociedade portuguêsa e do papel da neutralidade que o Estado devia

6 "Lei da separação do Estado das igrejas", Diário do Governo, n. ${ }^{\circ}$ 92, 21 de Abril de 1911, p. 3.

7 SEABRA, João. O Estado e a Igreja em Portugal no início do século XX, [...], p. 84 .

8 Protesto collectivo dos Bispos Portuguezes contra o Decreto de 20 d'abril de 1911, que separa o Estado da Egreja, s.1., s.e., 6 de Maio de 1911, p. 2, col. a; António de Jesus RAMOS, “A Igreja e a I República - A reacção católica em Portugal às leis persecutórias de 1910-1911”, Didaskalia, Lisboa, vol. XIII, 1983, pp. 264 a 268, 277 e 278; Fortunato de ALMEIDA, História da Igreja em Portugal, vol. III, Porto, Civilização Editora, 1970, pp. 545-546; Manuel Braga da CRUZ, As Origens da Democracia Cristã e o Salazarismo, Lisboa, Editorial Presença/Gabinete de Investigações Sociais, 1980, p. 249; e; Maria MOURA, A «Guerra Religiosa» sob a I República. O impacto da lei da separação, vol. I, Coimbra, Dissertação de Doutoramento em Letras, especialidade de História Contemporânea, apresentada à Faculdade de Letras da Universidade de Coimbra, 2004, pp. 72 a 74.

9 "Lei da separação do Estado das igrejas", [...], p. 6, cols. 1 a 3. 
fatalmente assumir perante as crenças religiosas e anti-religiosas dos seus cidadãos" 10 .

Prosseguindo com a efectivação do plano estabelecido procedeu-se assim à nacionalização de um vasto conjunto de monumentos emblemáticos e de opulentas colecções artísticas, maioritariamente pertencentes à Igreja Católica, de modo a poder disponibilizar ao grande público o património arquitectónico e o espólio artístico mais representativo da história Pátria. Com o dever patriótico de proteger o que restava da herança histórica e artística nacional, o novo Governo "fez leis especiais e criou, com não pequeno sacrificio do Tesouro, o Museu Machado de Castro e outros institutos similares" 11.

Durante séculos o centro cultural e científico por excelência de Portugal, Coimbra mantinha desde os finais do século XVIII uma firmada experiência na cultura museológica, embora assente no coleccionismo dos gabinetes de experimentalismo pombalinos estabelecidos em torno do Museu de História Natural. Mais tarde, na segunda metade da centúria de Oitocentos, além de surgirem outros organismos académicos complementares, foram criados o Museu de Antiguidades do Instituto de Coimbra (1874-1912), o Museu de Arte Industrial da autarquia (1889-1891), e o Museu da Escola de Desenho Industrial Brotero (1891-1898), cujos acervos acabariam, mais tarde, por ser reencaminhados para uma única instituição na cidade ${ }^{12}$.

Ora é precisamente neste contexto cultural e museológico que surge no panorama conimbricense a figura incontornável de António Augusto Gonçalves (1848-1932). Republicano e pedagogo desde os tempos mais remotos da sua mocidade, Augusto Gonçalves iria agora dedicar a sua vida a lutar pela educação e consciencialização artística do povo através da implementação de uma política cultural sedimentada no

${ }^{10}$ Um ano depois, a Lei da Separação era efusivamente celebrada em Coimbra com algumas casas embandeiradas e iluminadas ao som dos foguetes. Ao povo de Coimbra, Coimbra, Tipografia Reis Gomes, 20 de Abril de 1914, p. 1; "Lei da Separação", A Província, n. 5, Coimbra, 23 de Abril de 1912, p. 3, col. 1; e; António de Jesus RAMOS, “A Igreja e a I República1”, [...], p. 256.

${ }^{11}$ T.C., "O Cristo da Igreja de Santa Cruz", A Província, n. 95, Coimbra, 4 de Março de 1913, p. 1, col. 5.

${ }^{12}$ Henrique Coutinho GOUVEIA, Museus de Coimbra. Da I Exposição Distrital à organização do Museu Machado de Castro, Coimbra, Coimbra Editora, 1980, pp. 17 a 21. 
património histórico resgatado dos conventos e igrejas, assim como na (re)fundação de novas unidades museológicas ${ }^{13}$.

Conhecedor da debilidade cultural portuguesa, o seu nome ficaria para sempre associado às principais instituições da cidade, participando na fundação da Escola Livre das Artes do Desenho, em 1878; na organização das colecções do Museu da Câmara Municipal, em 1889, e do Museu de Arte Industrial, em 1890; nas campanhas de reintegração artística da primitiva catedral de Santa Maria, em 1893; na reorganização do acervo do Museu do Instituto de Coimbra em 1895, mais de vinte anos depois da sua inauguração, e, efemeramente, na superintendência dos Palácios Nacionais nos últimos meses de $1910^{14}$.

Após uma momentânea passagem pelos bancos da Universidade de Coimbra, Augusto Gonçalves foi convidado a leccionar a cadeira de desenho como professor na então denominada Faculdade de Filosofia. Pelas capacidades científicas e pedagógicas demonstradas acabaria por ser indigitado para o cargo de professor extraordinário de História da Arte e Estética, ainda que sem sucesso, por António de Vasconcelos (1860-1941), durante a primeira sessão do Conselho da Faculdade de Letras da Universidade de Coimbra, em 29 de Julho de $1911^{15}$.

${ }^{13}$ Em 1878, no artigo publicado na Lucerna, Augusto Gonçalves clamava pela criação de um museu artístico em Coimbra. Entretanto, como vereador da minoria republicana na autarquia local, conseguira fundar o museu municipal, que Costa Alemão implacavelmente encerrou. "O Museu Machado de Castro", A Província, n. 43, Coimbra, 3 de Setembro de 1912, p. 1, cols. 4-5.

${ }^{14}$ Costa RODRIGUES, "Mestre Gonçalves de Coimbra", António Augusto Gonçalves. Homenagem do "Instituto de Coimbra», separata de O Instituto, vol. CVIII, Coimbra, Coimbra Editora, Limitada, 1946, p. 7; Carlos SERRA, António Augusto Gonçalves. O percurso museológico, Coimbra, Dissertação de Mestrado em Museologia e Património Cultural apresentada à Faculdade de Letras da Universidade de Coimbra, 2002, p. 110; e; "GONÇALVES, António Augusto", Grande Enciclopédia Portuguesa e Brasileira, vol. XII, Lisboa/Rio de Janeiro, Editorial Enciclopédia, Limitada, s.d., p. 552, col. a.

${ }^{15}$ Porém, Gonçalves viu goradas as tentativas de assumir funções académicas na recém-nascida Faculdade de Letras, estabelecida por decreto de 9 de Maio de 1911, com a finalidade de promover o progresso e a divulgação da "alta cultura intelectual no domínio das ciências filosóficas, filológicas, históricas e geográficas". Uma vez mais, ao declinar o convite, alegando motivos pessoais, sugeria o nome de Joaquim de Vasconcelos. No opúsculo d'A Faculdade de Letras da Universidade de Coimbra ao País, o seu autor, anónimo, atestou que 
Sem tempo a perder, Augusto Gonçalves, a 30 de Dezembro de 1910, três meses depois da implantação da República, pressionava já os vários dos ministros do Governo procurando obter o seu beneplácito para a constituição de uma rede nacional de museus regionais, onde pudessem ser reunidos os principais "capitulos da história do trabalho nacional"16. O seu principal argumento incidia na necessidade de apostar no progresso moral e educativo das classes mais desfavorecidas e na defesa do património histórico da Nação. Nos inícios do ano seguinte anunciava a pretensão em fundar uma instituição similar em Coimbra com o espólio proveniente dos mosteiros e igrejas da região ${ }^{17}$.

A resposta ao seu pedido chegaria com a homologação do decreto-lei de 20 de Maio de 1911, no qual era nomeado coordenador dos arrolamentos de arte no distrito de Coimbra, seguido dos diplomas de 26 de Maio de 1911, que instituía o Museu de Machado de Castro "organizado principalmente no intuito de offerecer ao estudo publico collecções e exemplares da evolução da historia do trabalho nacional", uma riqueza cultural "destinada á educação do gosto publico e á aprendizagem das classes operarias" ( $\left.\operatorname{art}^{\circ} .39 .^{\circ}\right)$-, e o de 24 de Junho seguinte, no qual seria nomeado como director do recém-criado estabelecimento estatal ${ }^{18}$.

\footnotetext{
"se tivesse podido corresponder ao apêlo, que oportunamente lhe foi, com amiga insistencia, dirigido, no grupo dos Professores brilharia com o seu grande mérito o nome do Prof. Antonio Augusto Gonçalves". Manuel Augusto RODRIGUES (Direcção de), Memoria Professorum Vniversitatis Conimbrigensis (1772-1937), Coimbra, Arquivo da Universidade de Coimbra, 1992, pp. 55, 280, 295, 305; A Faculdade de Letras da Universidade de Coimbra ao País, Coimbra, Tip. França Amado, 1919, p. 18; Carlos SERRA, António Augusto Gonçalves, [...], pp. 51,74; e; "GONÇALVES, António Augusto", Grande Enciclopédia Portuguesa e Brasileira, [...]., p. 552, col. a.

16 "O Museu Machado de Castro", A Província, n. 112, Coimbra, 6 de Maio de 1913 , p. 1, col. 4.

${ }^{17}$ António GONÇALVES, Ao Governo da Republica, Coimbra, s.e., 30 de Dezembro de 1910, p. 1; "Sociedade de Defeza e Propaganda de Coimbra", Notícias de Coimbra, Coimbra, 21 de Janeiro de 1911, p. 2, col. 1; e; "Museu d'arte", Gazeta de Coimbra, n. ${ }^{\circ}$ 14, 16 de Agosto de 1911, p. 2, col. 4.

${ }^{18} \mathrm{O}$ diploma criava então os novos fundamentos para o ensino das Belas-Artes e organizava os principais serviços dos museus e do património histórico nacionais. "Decreto-lei 26 de Maio de 1911", Diário de Governo, n. ${ }^{\circ}$ 124, 29 de Maio de 1911, p. 26; GHC, Espólio particular de António Augusto Gonçalves, "Nota informativa António Gonçalves", 3 de Setembro
} 
Emancipando a Igreja "dos liames civis que a profanavam"19, aliviando-a assim do seu pesado fardo patrimonial - pois os edifícios religiosos corriam dois perigos: "o abandono ou a devoção. E era tão prejudicial um como o outro" 20 -, procurava agora o edifício ideal para materializar o seu projecto.

Em carta enviada ao presidente da Comissão Jurisdicional dos Bens das Extintas Congregações, datada de 31 de Outubro de 1911, o director indicava então como monumento eleito, entre um conjunto de outros apontados em praça pública, o Paço Episcopal, o "unico edificio accomselhado a este effeito que em Coimbra existe, que ultimamente tem sido apontado pela opinião unanime da cidade e solicitado pelas instancias de entidades officiaes e de representação"21.

Assim, convencido, impunha medidas céleres: "ou é cedida a residencia episcopal de Coimbra ou esta resolução encontra tergiversações, e toda essa valiosa herança corre risco de pouco a pouco, se hir defraudando e sumindo"22. Ao tomar conhecimento da resignação do bispo-conde D. Manuel Correia de Bastos Pina (1830/1872-1913), em virtude do conflito despoletado pela publicação de uma pastoral, e da obstinação do novo governador diocesano, o cónego José Alves Mattoso (1860-1952), que decidira desafiar o Governo ${ }^{23}$, Gonçalves conseguira reunir facilmente o apoio da vereação para votar na ocupação do paço.

de 1912; "Museu Machado de Castro de Coimbra ", Notícias de Coimbra, n. ${ }^{\circ}$ 392, Coimbra, 24 de Junho de 1911, p. 1, col. 4; e; Costa RODRIGUES, "Mestre Gonçalves de Coimbra", António Augusto Gonçalves. Homenagem do «Instituto de Coimbra», separata de O Instituto, vol. CVIII, Coimbra, Coimbra Editora, Limitada, 1946, p. 19.

${ }^{19}$ AG. "Maus prenuncios", O Despertar, n. ${ }^{\circ}$ 810, 28 de Fevereiro de 1925, p. 1 , col. 4 .

20 "Museu Machado de Castro", A Província, n. ${ }^{\circ}$ 119, Coimbra, 30 de Maio de 1913 , p. 1, col. 5.

${ }^{21}$ MNMC, Copiador I, António GONÇALVES, "Relatório enviado ao Presidente da Comissão Jurisdicional dos Bens das Extintas Congregações", 31 de Outubro de 1911, fol. 7; e; "Museu d'arte", Gazeta de Coimbra, n. . 17, 26 de Agosto de 1911, p. 1, col. 4.

${ }^{22}$ MNMC, Copiador I, António GONÇALVES, "Relatório enviado ao Presidente da Comissão Jurisdicional dos Bens das Extintas Congregações", 31 de Outubro de 1911, fol. 7 e v.

23 "Bispo Conde", Gazeta de Coimbra, n. ${ }^{\circ}$ 46, 6 de Dezembro de 1911, p. 1, cols. 1 a 4; e; José Alves MATTOSO, Circular, Coimbra, Typographia França 
Presidindo à sessão camarária de 6 de Dezembro de 1911, cargo assumido após a saída de Sidónio Pais (1872-1918), apresentava a "grande obra de civilisação, de respeito pela arte e de aperfeiçoamento nacional" de que Coimbra há muito necessitava ${ }^{24}$. Dessa reunião extraordinária resultaram as petições enviadas aos ministros da Justiça e do Interior. Enquanto na carta dirigida ao primeiro explorou a antiguidade e espacialidade do edifício, "de traça singular, tipo suntuoso de arquitectura civil e moradia privilegiada do seculo XVI", na de Silvestre Falcão (?-1927), antigo Governador Civil de Coimbra, Gonçalves coloca a hipótese do fracasso do projecto museológico caso não fosse cedido o "unico edificio disponivel que em Coimbra existe, apropriado a uma instalação proficua e ampla" da instituição ${ }^{25}$.

$\mathrm{Na}$ verdade, analisando alguns dos seus escritos é possível comprovar que há muito havia reflectido na escolha deste imóvel para estabelecimento do Museu: "que o paço episcopal desta cidade não tivesse outra applicação que não fosse para nelle se installar o «Muzeu Machado de Castro»". Assegurava, pois, que nenhum outro satisfazia "completamente ás condições indispensaveis para se fazer essa instalação, que requer amplas salas, fartas de luz e com situação desafogada no centro da cidade"26.

Amado, 31 de Dezembro de 1911, p. 1; António DIAS, “Queixa do Ministerio Publico" [...] pp. 26 a 29.

${ }^{24}$ Os vereadores presentes eram Manuel Augusto Rodrigues da Silva, Frederico Pereira da Graça, Francisco Vilaça da Fonseca, Albino Caetano da Silva Pinto, Júlio Vieira de Figueiredo Fonseca, Adriano Viegas da Cunha Lucas, Adriano Viegas da Cunha Lucas e Floro Henriques. AHM, Livro de actas das sessões da Câmara Municipal de Coimbra (1911-1912), fls. 80 e 81; e; "Musêu d'Arte", Gazeta de Coimbra, n. '47, 9 de Dezembro de 1911, p. 1, col. 2 .

25 "Musêu d'Arte", Gazeta de Coimbra, n. . 47, 9 de Dezembro de 1911, p. 1, col. 2; e; "Camara Municipal", Gazeta de Coimbra, n. . 51, 23 de Dezembro de 1911, p. 3, col. 1 .

${ }^{26}$ Outros edifícios residenciais episcopais viriam a ser tomados para além do de Coimbra, como o de Braga, Bragança, Castelo Branco, Évora, Faro, Funchal, Guarda e Lamego. Deste conjunto, o palácio de Évora viria a receber o espólio do Museu Cenáculo, o de Bragança, daria origem ao Museu Regional de Obras de Arte, Peças Arqueológicas e Numismática de Bragança, ambos fundados em 1915, e no de Lamego, num projecto iniciado pelo próprio bispo residencial antes de 1910, era, em 1917, constituído o Museu de Obras de Arte, Arqueologia e Numismática de Lamego. AHM, 
Entrementes, enquanto D. Manuel Correia de Bastos Pina viria a abandonar a residência episcopal por "sua libérrima vontade, porque não foi intimado; nem sequer a mais ligeira insinuação lhe foi dirigida" ${ }^{27}$, segundo as palavras distorcidas de Augusto Gonçalves, o cónego Alves Mattoso, após sucessivas críticas dirigidas ao Estado, acabaria por ser desterrado para o Luso. Uma vez decapitado o governo diocesano dispunha agora de plena liberdade para proceder à ocupação do monumento...

Intrigante testemunho foi encontrado no espólio do antigo director do Arquivo da Universidade de Coimbra, António Gomes Rocha Madahil (1893-1969). Conta Madahil que "quando Gonçalves e a comissão republicana, depois da implantação da Rep ${ }^{\mathrm{a}}$. se dirigiram ao Paço do Bispo $\mathrm{p}^{\mathrm{a}}$ tratarem directamente com ele da situação do Paço [provavelmente entre Novembro e Dezembro de 1911], Eugénio de Castro $^{28}$ que estava à janela à espreita, fez apressadamente sair o Bispo pelo portão do Arco do Bispo, com destino a Carregosa, dizendo-lhe q̃ a comissão o vinha expulsar do Paço: em seguida recebeu ele a comissão, ao alto da escada do lado direito do pátio, e disse-lhe q̃ o Bispo estava em Carregosa. Chaves de Almeida diz que o fez $\mathrm{p}^{\mathrm{a}}$. ficar sosinho no Paço, não sabe com que fim" "29.

De facto, o prelado ao regressar a Coimbra no dia 27 de Fevereiro de 1912, dezassete dias após a tomada do paço, foi forçado a estabelecer a sua residência, bem como os múltiplos serviços da Cúria, no Seminário

Livro de actas das sessões da Câmara Municipal de Coimbra (1911-1912), fls. 80 e 81; "Musêu d'Arte", Gazeta de Coimbra, n. ${ }^{\circ}$ 47, 9 de Dezembro de 1911, p. 1, col. 1; António GONÇALVES, Depoimento para ajuntar ao volumoso processo dos malfeitores, Coimbra, Minerva Central, 1912, p. 21; e; Milton PACHECO, "(Es)Paços para a República: A musealização dos paços episcopais e a democratização cultural em Portugal durante a I República”, I República e Republicanismo. Congresso Histórico Internacional, Assembleia da República, [no prelo, pp. 5-6].

${ }^{27}$ A. GONÇALVES, Enumeração das obras preparativas para a instalação do Museu Machado de Castro, Coimbra, Tip. de O Despertar, 1929, p. 6; D. Manuel Correia de Bastos PINA, [Nota Pastoral do Bispo de Coimbra], Coimbra, Typ. França Amado, 27 de Fevereiro de 1912, p. 2.

${ }^{28} \mathrm{O}$ célebre escritor e professor conimbricense foi casado com uma sobrinha do prelado diocesano.

${ }^{29} \mathrm{GHC}$, Espólio particular de António Gomes Rocha Madahil, pasta B-11, "Assuntos diversos. Actividade Política, testemunho de Chaves de Almeida", 18 de Fevereiro de 1949”, fol. 1. 
Diocesano de Jesus, Maria e José. Daqui emanou uma nota pastoral, na qual manifestava sua angústia pelos "tempos de perseguição religiosa tão cortada de asperesas, trabalhos e sofrimentos" $"$.

Resolvida a questão do espaço, Augusto Gonçalves, em 1912, solicitou à direcção do Instituto de Coimbra, através do Conselho de Arte e Arqueologia da $2^{\mathrm{a}}$. Circunscrição, a cedência das colecções artísticas e arqueológicas expostas no Museu de Antiguidades, que ele próprio ajudara a reorganizar e fora responsável pela conservação alguns anos antes ${ }^{31}$. Considerava, de facto, o Museu Machado de Castro "a sequência progressiva do Museu do Instituto" - e por tal motivo a razão da sua extinção -, onde anos antes desenvolvera os primeiros projectos museológicos em torno da secção de antiguidades ${ }^{32}$.

Nove anos mais tarde, o director poderia retribuir o favor ao autorizar a instalação do famoso grémio científico e literário conimbricense nas dependências do Museu Machado de Castro, na denominada casa do Arco do Bispo, junto da Rua do Salvador ${ }^{33}$. E aqui permaneceria o Instituto de Coimbra, com a sua biblioteca e gabinetes de investigação, até Junho de 1940, quando foi planeada a instalação de uma secção de etnografia do Museu ${ }^{34}$.

${ }^{30}$ D. Manuel Correia de Bastos PINA, [Nota Pastoral do Bispo de Coimbra], [...], p. 2 .

31 "Museu de Antiguidades", A Província, n. 118, Coimbra, 27 de Maio de 1913 , p. 1, col. 3 .

${ }^{32}$ MNMC, Copiador I, António GONÇALVES, “Ofício n. 335 enviado ao Conde do Ameal", 11 de Agosto de 1921, fol. 85, v; e; despacho de 10 de Fevereiro de 1912, Diário de Governo, n. ${ }^{\circ}$ 36, Lisboa, 13 de Fevereiro de 1912, p. 603, col. 3.

${ }^{33}$ Anselmo de CARVALHO, "António A. Gonçalves", António Augusto Gonçalves. Homenagem do "Instituto de Coimbra», [...], pp. 1-2; MNMC, Correspondência expedida, Vergílio CORREIA, "Ofício n. . 3/228 enviado ao Director Geral do Ensino Superior e das Belas Artes", 19 de Outubro de 1936, fol. 1; Jorge SARAIVA, Academismo, Ideologia e História. O Instituto de Coimbra (1910-1945), Coimbra, Dissertação de Mestrado apresentada à Faculdade de Letras da Universidade de Coimbra, 1993, pp. 14 e 15; e; Carlos SERRA, António Augusto Gonçalves. O percurso museológico, [...], p. 140.

${ }^{34}$ Anselmo de CARVALHO, "António A. Gonçalves", António Augusto Gonçalves. Homenagem do "Instituto de Coimbra», [...], p. 3; e; MNMC, Correspondência expedida, Vergílio CORREIA, "Ofício n. . 4/66 enviado ao Director Geral do Ensino Superior e das Belas Artes”, 26 de Junho de 1940, fol. 1. 
Concluído o arrolamento dos bens provenientes das casas religiosas de Santa Clara-a-Nova, de Santa Teresa, das Ursulinas, em Coimbra, e do Convento do Desagravo, no Louriçal, procedia-se ao depósito imediato no paço de modo a legitimar a sua ocupação ${ }^{35}$. Assim, por despacho legal de 10 de Fevereiro de 1912, o Palácio da Mitra Episcopal, que durante séculos fora residência e símbolo de poder dos bispos de Coimbra, era cedido oficialmente para receber o Museu Machado de Castro ${ }^{36}$.

Mas o processo, que sofrera algumas contrariedades, foi finalizado no momento em que se decidiu que o paço, agora propriedade do Estado, fosse arrendado à edilidade, com uma renda no valor de $400 \$ 000$ réis anuais ${ }^{37}$. Estabelecidos os acórdãos legais entre as entidades públicas, nos inícios de Março, procedia-se à entrega legal e definitiva da residência episcopal ${ }^{38}$. No entanto, o edifício que deveria receber tais preciosidades estava em péssimo estado de conservação segundo o testemunho de João Couto: «Não se pode conjecturar, elucida-nos Gonçalves, o estado de indecorosa imundície e assolador detrimento,

${ }^{35} \mathrm{GHC}$, Espólio particular de António Augusto Gonçalves, pasta C-30, "Telegrama recebido a 12 de Novembro de 1912", fol. 1; "Ofício dirigido ao Administrador do Concelho, 8 de Janeiro de 1912", fol. 1; "Ofício n. ${ }^{\circ}$, dirigido pelo Administrador do Concelho a António Augusto Gonçalves, 10 de Janeiro de 1912”, fol. 1; MNMC, Copiador I, António GONÇALVES, "Comunicado enviado ao Delegado do Procurador-Geral da República", 26 de Janeiro de 1912, fol. 8; e; "Decreto com força de lei de 8 de Outubro", Diário do Governo, n. . 4, 10 de Outubro de 1910, p. 18, col. 1;

${ }^{36}$ MNMC, Copiador I, António GONÇALVES, “Ofício n. 335 enviado ao Conde do Ameal", 11 de Agosto de 1921, fol. 85, v; e; "Despacho de 10 de Fevereiro de 1912", Diário de Governo, n. '36, Lisboa, 13 de Fevereiro de 1912 , p. 603 , col. 3 .

${ }^{37}$ As rendas nunca foram liquidadas uma vez que a edilidade declarava que as despesas deveriam ser pagas pelo Ministério da Instrução Pública. MNMC, Copiador II, Vergílio CORREIA, "Ofício n. ${ }^{\circ} 547$ enviado Director Geral do Ensino Superior e das Belas Artes", 4 de Abril de 1933, fol. 93 e v. MNMC, Copiador de 15 de Junho de 1911 a 19 de Março de 1924, António GONÇALVES, "Ofício n. ${ }^{\circ} 81$ enviado ao Presidente da Câmara Municipal de Coimbra", 8 de Junho de 1920, fol. 72.

${ }^{38}$ Conselho de Arte e Arqueologia da Segunda Circunscrição, Copiador da correspondência expedida (1911-1924), "Ofício dirigido ao Director Geral da Instrução Secundária, Superior e Especial, a 23 de Maio de 1912”, p. 15 apresentado por Carlos SERRA, António Augusto Gonçalves. O percurso museológico, [...], p. 141. 
em que se achava o edifício do lado do sul». Era uma situação idêntica àquela em que encontrara o Museu do Instituto quando a direcção deste lhe foi entregue" 39 .

Além do mais, qual o destino a dar à avultada documentação proveniente do cartório diocesano? Livrando-se da responsabilidade da protecção desses fundos, o director, em carta dirigida ao governador civil, insinuava que "os funcionarios da Camara eclesiastica deixaram ao abandono no paço episcopal quantidade consideravel, centenas de volumes, do registo parochial", e solicitava a sua imediata remoção ${ }^{40}$. Este era na verdade um discurso bastante favorável a Augusto Gonçalves tendo em conta que o paço, alvo de uma ampla campanha de obras de beneficiação desde os finais do século XIX, havia sido ocupado recentemente.

Após diversos malabarismos, apostava agora na revalorização do monumento segundo a cultura artística imperante na época: "A verdadeira civilização consiste no aproveitamento da sabedoria do passado, aperfeiçoando o util e eliminando o supérfluo"41. Estaria a integridade arquitectónica do edifício, já afectado pelas últimas obras de restauro, em perigo novamente?

Face à nova utilização do Monumento Nacional era necessário proceder a um profundo plano geral de reorganização e readaptação espacial de modo a acolher e a exibir convenientemente as importantes colecções artísticas, arqueológicas e industriais. Elaborado pelo próprio

${ }^{39}$ MNMC, Copiador I, António GONÇALVES, "Comunicado enviado ao Governador Civil", 17 de Julho de 1912, fol. 12; A. GONÇALVES, Enumeração das obras preparativas [...] pp. 4 a 8; João COUTO, “O Professor António Augusto Gonçalves, fundador do Museu de Machado de Castro", Homenagem do «Instituto de Coimbra», O Instituto, vol. CVIII, [...], pp. 52-53.

${ }^{40}$ MNMC, Copiador I, António Augusto GONÇALVES, "Comunicado enviado ao Conservador do Registo Civil”, 6 de Agosto de 1912, fol. 13; Copiador I, "Comunicado enviado ao Governador Civil ", 17 de Julho de 1912, fol. 12 e v; Ana BANDEIRA, "O A.U.C. nas suas relações com a Inspecção Superior de Bibliotecas e Arquivos, a Direcção-Geral de Finanças e a Comissão Administrativa de Bens Cultuais", pp. 103, 111 e 112 e Júlio RAMOS, "As incorporações dos arquivos judicial, notarial e paroquial", Boletim do Arquivo da Universidade de Coimbra, vols. XVII-XVIII, Coimbra, Arquivo da Universidade de Coimbra, 1997-1998, p. 136.

${ }^{41}$ Pedro de Azevedo, O Archeologo Português, vol. XII, ns ${ }^{\circ} 1$ a 4, Lisboa, Imprensa Nacional, Janeiro a Abril de 1907, p. 34. 
Gonçalves, muito provavelmente em Março de 1912, o plano Para o antigo paço do Bispo contou com a avaliação do arquitecto Augusto Carvalho da Silva Pinto (1865-1938), "orago das dificuldades", e com o auxílio material da Direcção das Obras Públicas do Distrito de Coimbra, na pessoa de Manuel Rodrigues da Silva, um "espírito cultivado em coisas da arte" $"$.

No mesmo mês, o processo era submetido à aprovação da entidade distrital responsável pela cedência dos monumentos e artefactos históricos, sendo posteriormente remetido para o Ministério do Interior. Decidido em levar por diante a sua obra recorreu pessoalmente ao ministro Silvestre Falcão, o único e influente recurso humano que the restava para a concretização desta empresa ${ }^{43}$.

Somente a 28 de Maio de 1912, o Governador Civil de Coimbra, João Mendes de Vasconcellos, de acordo com despacho $3^{\text {a }}$ Repartição da Direcção Geral da Contabilidade Pública do Ministério do Interior, oficiava a Augusto Gonçalves a liquidação das primeiras contas e a autorização para prosseguir com o empreendimento. Esta primeira intervenção, forçosamente destrutiva para proceder às adaptações condizentes às novas funções museológicas, só terminaria um ano depois da inauguração do $\mathrm{Museu}^{44}$.

Mais tarde, em 10 de Junho de 1912, foi enviado o requerimento às autoridades competentes para iniciar a incorporação do mobiliário seleccionado do acervo proveniente do Paço Episcopal, e, no dia seguinte, um outro dirigido à direcção do Instituto de Coimbra para

${ }^{42}$ A. GONÇALVES, Enumeração das obras preparativas, [...], p. 9; GHC, Espólio particular de António Augusto Gonçalves, pasta C-30, "Apontamento pessoal de uma carta dirigida ao Ministério do Interior", 9 de Abril de 1912; "Para o antigo paço do Bispo, 1912 (Março?)", fol. 1; "Silva Pinto", Gazeta de Coimbra, n. ${ }^{\circ} 72,9$ de Março de 1912, p. 1, col. 3. MNMC, Correspondência recebida, Paulo BARROS, "Ofício expedido pela Direcção das Obras Públicas", 10 de Fevereiro de 1917, fol. 1 .

${ }^{43}$ GHC, Espólio particular de António Augusto Gonçalves, pasta C-30, "Apontamento pessoal de uma carta dirigida ao Ministério do Interior, 9 de Abril de 1912", fol. 1.

${ }^{44} \mathrm{GHC}$, Espólio particular de António Augusto Gonçalves, pasta C-30, "Ofício n. ${ }^{\circ} 155$ exarado pelo Governador Civil de Coimbra, João Mendes de Vasconcelos, a 28 de Maio de 1912", fol. 1; e; "Informação exarada do Ministério do Interior, em 1912 (Junho?)", fol. 1. 
a entrega das suas colecções, que acabariam por ser transferidas entre Agosto de 1912 e Setembro de $1913^{45}$.

Informado a 31 de Outubro de 1912 de que as obras iriam prosseguir conforme planeado, Gonçalves, depois de ter sido amplamente criticado por demorar na instalação do acervo ${ }^{46}$, mandou, em 21 Dezembro, noticiar que: "na antiga residência episcopal de Coimbra [...] procede-se com atividade á instalação dos objectos até aqui expostos no Instituto desta cidade" ${ }^{47}$.

Pondo em prática as suas faculdades artísticas organizou as galerias dedicadas ao período medieval e renascentista, "celebres tanto pela importancia das peças como pela graciosidade da disposição com que soube valorizá-las", recorrendo à utilização de materiais económicos ${ }^{48}$. Contiguamente encontrava-se o núcleo de arte industrial com as secções de "serralharia e de mil outras antiqualhas ali dispostas para servir de inspiração e modelo aos estudantes da Escola Livre das Artes do Desenho e da Escola Industrial Brotero", duas instituições fundadas por $\mathrm{si}^{49}$.

${ }^{45}$ MNMC, Copiador I, António GONÇALVES, "Requerimento enviado pelo Museu ao Presidente da Comissão Jurisdicional dos Bens das Extintas Congregação Religiosas", 10 de Junho de 1912, fol. 8, v; AME, Correspondência expedida, Copiadores 1911-1924, "Ofício dirigido pelo Conselho de Arte e Arqueologia da $2^{\circ}$ Circunscrição Artística ao Presidente do Instituto de Coimbra", 11 de Junho de 1912", p. 23; e; "Museu Machado de Castro", A Província, n. 148, Coimbra, 19 de Setembro de 1913, p. 1, col. 3.

46 "O Museu Machado de Castro", A Província, n. 43, Coimbra, 3 de Setembro de 1912, p. 1, cols. 4 e 5.

${ }^{47} \mathrm{GHC}$, Espólio particular de António Augusto Gonçalves, pasta C-30, "Ofício exarado por Cunha Barros, da Direcção das Obras Públicas do Distrito de Coimbra, a 31 de Outubro de 1912", fol. 1; e; "Musêu Machado Castro", Gazeta de Coimbra, n. ${ }^{\circ}$ 154, 21 de Dezembro de 1912, p. 2, col. 6.

${ }^{48}$ Vergílio CORREIA, "Como se faz um Museu", Diário de Coimbra, n. ${ }^{\circ} 1689,7$ de Maio de 1935 , p. 1.

${ }^{49}$ Coleccionadas com um espírito crítico e superior, "como um grande mestre e um grande educador que é", Gonçalves organizara "um nucleo de educação artística raro e que não deve passar despercebido aos artistas de Coimbra que nele terão com a melhor fonte de lição historica, a melhor fonte de inspiração", concluiria Teixeira de Carvalho. T.C., "Museu Machado de Castro", A Província, n. 155, Coimbra, 14 de Outubro de 1913, p. 1, col. 1; e; João COUTO, “O Professor António Augusto Gonçalves, fundador do Museu Machado de Castro", [...] p. 54. 
Tal como procedera na reorganização do acervo do Museu de Antiguidades do Instituto de Coimbra, instalado no primitivo Colégio de São Paulo, o Eremita, a sua principal preocupação foi obter as melhores condições expositivas, através do maior aproveitamento possível da iluminação natural e do estabelecimento de um percurso interno coerentemente pedagógico ${ }^{50}$. Porém, ao não conseguir repetir o mesmo prodígio em algumas das secções museológicas nos pisos superiores, devido aos contínuos entraves burocráticos que impunham a limitação das verbas económicas, levantar-se-iam novamente na imprensa local outras vozes críticas, como a de Fortunato de Almeida (1869-1933) que classificaria o estabelecimento de "armazem de bugigangas" 51.

Em virtude das magras dotações para erigir as infra-estruturas programadas $^{52}$, e perante a urgência em abrir o Museu ao público, Augusto Gonçalves dirigiu-se ao primeiro-ministro Bernardino Machado (1851-1944) - antigo professor universitário, director do Instituto de Coimbra e maçom da loja Perseverança, portanto alguém bem próximo da sua pessoa -, para obter as devidas autorizações que lhe permitissem organizar um primeiro leilão com o recheio da residência episcopal. A primeira sessão viria a decorrer nas próprias instalações da instituição, às 12 horas do dia 20 de Abril de 1913, continuando as hastas públicas nos domingos subsequentes ${ }^{53}$.

${ }^{50}$ Contudo, as obras efectuadas revelar-se-iam prejudiciais às colecções expostas, pois as salas atingiriam temperaturas muito elevadas nos meses mais quentes, obrigando à remoção das obras de pintura, privando assim "os estudiosos e o publico d'uma das mais interessantes e valiosas secções" do país. A. GONÇALVES, Enumeração das obras preparativas [...] p. 5; MNMC, Copiador I, António GONÇALVES, "Comunicado enviado a Director Geral das Obras Públicas", 10 de Setembro de 1913, fol. 18; "Comunicado enviado ao Presidente Ministro", 26 de Agosto de 1914, fol. 30; e; "Comunicado enviado ao Director da Repartição das Obras Públicas”, 26 de Agosto de 1914, fols. 29.

${ }^{51}$ MNMC, Copiador I, António GONÇALVES, "Comunicado enviado ao Governador Civil de Coimbra", de 14 de Outubro de 1914, fol. 32; e; Z. [António Augusto GONÇALVES], "Banalidades", O Debate, n. ${ }^{\circ}$ 121, 9 de Maio de 1915, p. 1, col. 3 .

${ }^{52}$ MNMC, Copiador de 15 de Junho de 1911 a 19 de Março de 1924, António GONÇALVES, "Ofício n. . 5 enviado ao Presidente do Conselho de Arte e Arqueologia”, 28 de Janeiro de 1922, fol. 89.

${ }^{53} \mathrm{GHC}$, Espólio particular de Martins de Carvalho, Pastas 36 e 55, "Leilão, de 20 de Abril de 1913", [impresso na Tipografia Moderna], cartão único. Aliás, 
Afinal de contas, o homem que tanto criticara a acção imprudente do Governo Liberal, a quem responsabilizara pela perda exacerbada do património artístico das principais casas conventuais do país ao longo de todo o século XIX, acabaria por seguir o mesmo estratagema de financiamento ao colocar à venda o espólio da residência episcopal de Coimbra. Não só esta política retalhista fora seguida por todo o país, nomeadamente noutros museus instalados em paços episcopais, como os de Évora e Bragança ${ }^{54}$, como em Abril de 1914 ainda circulavam nos jornais da cidade os anúncios dos leilões organizados com os bens artísticos dos conventos e mosteiros locais ${ }^{55}$.

Este acontecimento é de facto surpreendente, sobretudo, quando confrontado com o testemunho que o próprio redigiu dez anos mais tarde sobre a dispersão do património artístico proveniente das casas religiosas: "Quando do último encerramento das congregações religiosas, os crimes ofensivos da arte; os latrocínios impunes e a devastação leiloada, a vil prêço, de artefactos portugueses, recusados a Museus, foram como um ferrete a carimbar a época!" 56.

A inoperância da Lei da Separação permitira, de facto, um banquete lauto para os antiquários, pois "não foram previdentemente acauteladas preciosas reliquias d'arte que continuaram expostas aos baldões do acaso. E perdeu-se o ensejo único, para, sem resistencias, fazer selecção e garantir contra desatinos, desastres e fraudes, artefactos de excepcional importancia, em poder de juntas de paroquia e colectividades do

nesse mesmo ano seria organizado ainda outro leilão com os bens provenientes do extinto cartório da Sé: os "diferentes objectos de ouro e prata, moveis e paramentos" pertencentes ao Cabido. "Leilão", Gazeta de Coimbra, n. " 205, 21 de Junho de 1913, p. 3, col. 3; "Paço episcopal", O Conimbricense, n. ${ }^{\circ}$ 5686, 24 de Maio de 1902, p. 3, col. 1; e; MNMC, Correspondência recebida, Pasta 1913-1929, "Telegrama de Bernardino Machado, de 17 de Setembro de 1913", fol. 1.

${ }^{54}$ Milton PACHECO, “(Es)Paços para a República: A musealização dos paços episcopais e a democratização cultural em Portugal durante a I República", [...], [no prelo, p. 24].

55 "Bens das Extintas Congregações Religiosas", A Província, n. 207, Coimbra, 17 de Abril de 1914, p. 3.

${ }^{56}$ A. GONÇALVES, Estatuária Lapidar [...] p. XI; Arte Flamenga, Coimbra, Museu Nacional de Machado de Castro, 1972, p. 3; e; Luis REIS-SANTOS, Catálogo de Arte Flamenga do século XVI, Coimbra, Museu Machado de Castro, 1954 ,pp. 25 e 34. 
divino", lamentava Gonçalves ${ }^{57}$. Mas as directrizes presentes nos sucessivos diplomas emitidos pela Direcção Geral dos Eclesiásticos eram suficientemente ambíguos para poderem ser aplicados consoante as necessidades e as pretensões de cada um ${ }^{58}$.

Julgamos que tenha sido a escassos meses da abertura, que José de Figueiredo (1872-1937), perante os círculos culturais de Lisboa, tenha afirmado que dentro em breve Portugal teria um museu excepcional, pois era o seu mentor Augusto Gonçalves, "uma das raras pessoas que no país queria alguma coisa e sabia o que queria" 59 .

Evocando o nome do grande escultor régio nascido em Coimbra, no ano de 1732, o Museu de Machado de Castro era finalmente inaugurado em 11 de Outubro de 1913, ao público em geral, recebendo logo em Abril seguinte a primeira visita de estudo dos alunos do Liceu Central de Pedro Nunes, de Lisboa ${ }^{60}$.

Adaptado forçosamente à função museológica, o monumento anunciava "á primeira vista, que por ali passou o dedo amestrado dum artista animado pelo fervoroso respeito por todos aqueles restos de epocas já distante". A 19 de Outubro seguinte, o Conselho de Arte e Arqueologia elogiava igualmente a obra do director como se verifica no louvor proferido: "Honra a Antonio Augusto Gonçalves, ao seu saber, á sua dedicação pela causa do Bello, ao seu sacrifício pela educação de todos, mas nomeadamente, das classes artísticas e profissionais de Coimbra, que em tal homem tinham o Mestre sabedor, modesto, condescendente e valiosissimo, que poucos poderiam igualar e nenhum exceder" ${ }^{\prime \prime}$.

${ }^{57}$ A. GONÇALVES, Enumeração das obras preparativas, [...], p. 4; "Exposição Preliminar", Arte e Arqueologia, n. . 1, Ano I, Coimbra, Imprensa da Universidade, 1930-1931, p. 7; e; Monitoria dirigida aos Srs. Ministros, Deputados e Senadores, ou quem suas veses fisér, Acêrca do Museu Machado de Castro de Coimbra, Coimbra, Tip. d'O Despertar, 1921, p. 4.

${ }^{58} \mathrm{GHC}$, Espólio particular de António Augusto Gonçalves, pasta C-30, "Informação exarada por Francisco Corrêa de Lima, da Direcção Geral dos Negócios Eclesiásticos do Ministério da Justiça, a 28 de Junho de 1912”, fol. 1.

${ }^{59}$ T.C.“A igreja de S. João de Almedina”, A Província, n. 213, Coimbra, 8 de Maio de 1914, p. 1, col. 3.

${ }^{60} \mathrm{MNMC}$, Correspondência recebida, "Pedido do Liceu Central de Pedro Nunes", 4 de Abril de 1914.

${ }^{61}$ Carlos SERRA, António Augusto Gonçalves [...] p. 144; "Museu Machado de Castro", Gazeta de Coimbra, n. ${ }^{\circ}$ 236, 15 de Outubro de 1913, p. 3, col. 4; 
Gonçalves conseguira por fim encetar a primeira fase do seu ambicioso projecto de educação nacional! Entretanto, com o Museu em funcionamento, começava-se a gizar a agora ocupação da contígua igreja de São João de Almedina e a transferência do Tesouro da Sé de Coimbra, nacionalizado em 20 de Abril de 1911 e integrado no Museu de Machado de Castro em 26 de Maio de 1911. Este decreto-lei, que reorganizara os serviços artísticos e arqueológicos em Portugal, considerava "uma secção d'este Museu o Museu de Arte Religiosa, instituído junto da Sé Catedral" (art. 39..$^{\circ}$, par. 2. ${ }^{\circ}$ ), mantendo-se no entanto como director o seu fundador, o bispo-conde D. Manuel Correia de Bastos Pina (art. 76. $\left.{ }^{\circ}\right)^{62}$.

Sendo convidado pelo ministro António José de Almeida (1866-1929) a participar na revisão do diploma elaborado por José de Figueiredo, julgamos que tenha sido ele próprio o responsável pela reelaboração do artigo $76^{\circ}$., no qual determinava que "o museu de arte religiosa, annexo á cathedral de Coimbra, fica declarado museu nacional, continuando sob a direcção do seu instituidor" ${ }^{63}$. Mas na verdade o prelado já se adiantara na tentativa de salvar o seu museu quando, em 14 de Fevereiro de 1911, decidiu enviar um ofício ao presidente do Governo Provisório, acompanhado de uma cópia da recém-publicada Noticia histórica e descriptiva dos principaes objectos de ourivesaria existentes no Thesoiro da Sé de Coimbra ${ }^{64}$. Nesse documento, insinuava o prelado que os novos organismos culturais criados pelo novo regime

e; Cyrillo Volkmar MACHADO, Collecção de Memorias relativa ás vidas dos pintores, e escultores, architectos, e gravadores portugueses e dos estrangeiros que estiverão em Portugal, Coimbra, Imprensa da Universidade, 1922, pp. 212 a 214.

62 "Decreto de Lei de 26 de Maio, reorganizando os serviços artisticos e archeologicos", Diario do Governo, n. . 124, Lisboa, 29 de Maio de 1911, p. 2246.

${ }^{63}$ Esta disposição seria reconfirmada com o decreto com força de lei de 26 de Maio seguinte. "Lei da separação do Estado das igrejas" [...] p. 1621; e; "Decreto de Lei de 26 de Maio, reorganizando os serviços artisticos e archeologicos", Diário do Governo, n. ${ }^{\circ}$ 124, Lisboa, 29 de Maio de 1911, p. 2246; e; Carlos SERRA, António Augusto Gonçalves. O percurso museológico, $[\ldots]$, p. 137.

${ }^{64} \mathrm{O}$ catálogo, publicado na Imprensa Académica de Coimbra em 1911, é da autoria de Eugénio de Castro e António Augusto Gonçalves. 
não deveriam prejudicar os existentes e nem ofender o sentimento e as tradições religiosas da Pátria ${ }^{65}$.

A partir das fontes documentais consultadas verificámos que Augusto Gonçalves decidira retardar o processo de incorporação do Tesouro de Pratas da Sé em respeito à figura do prelado - que classificara de mais nobre figura do episcopado português -, mas logo após o seu falecimento, ocorrido a 22 de Novembro de 1913, anunciou a ida a Lisboa para tratar desta questão com o ministro responsável ${ }^{66}$. $\mathrm{Na}$ verdade revelara até publicamente que nunca pretendera "em vida do sr. Bispo-Conde, fazer alguma coisa que S. Ex. ${ }^{\circ}$ a pudésse tomar falta de respeito pela sua obra" 67 .

Que laços uniriam estas duas personalidades? Ars gratia artis, a dedicação ao bispo que lhe permitira recuperar a glória passada da Sé Velha e edificara o primeiro bairro operário do país ou um pernicioso vínculo maçónico?

Entre as muitas dúvidas que estão ainda por responder sobre a biografia do insigne prelado $\mathrm{D}$. Manuel permanece a sua ligação à maçonaria ${ }^{68}$. Recorrendo uma vez mais à herança documental de

${ }^{65}$ D. Manuel Correia de Bastos PINA, Officio do Bispo de Coimbra ao Ex.mo Presidente do Governo Provisorio da Republica ácerca do Thesoiro da Sé da mesma cidade, Coimbra, Typ. França Amado, 1911, p. 8; e; Os Mosteiros de Lorvão e de Santa Clara e o Templo da Sé Velha, Coimbra, Typographia do Seminario, 1893, pp. 10, 18, 25.

${ }^{66}$ Em 1926, Augusto Gonçalves decidira promover a execução de um busto do prelado que visava reconhecer o contributo prestado pelo fundador do Tesouro da Sé. A peça, executada em bronze pelo artista Costa Mota (sobrinho), seria colocada na capela-mor da igreja de São João, durante a administração de Vergílio Correia. MNMC, Correspondência recebida, Joaquim RASTEIRO, "Carta enviada pela Junta de Freguesia de Almedina, Coimbra", 19 de Março de 1926, fol. 1; A. GONÇALVES, "Ourivesaria, Tecidos e Bordados no Museu Machado de Castro", Arquivo Coimbrão, vol. I, Coimbra, Tip. Coimbra Editora, 1924, p. 164; e; "Museu de Arte Sacra", Gazeta de Coimbra, n. ${ }^{\circ}$ 470, 26 de Janeiro de 1916, p. 1, col. 2; Correspondência expedida, Vergílio CORREIA, "Ofício n. ${ }^{\circ} 660$ Costa Mota", 29 de Maio de 1935, fol. 1; T.C., "Longe de ilusões", A Província, n. 200, Coimbra, 24 de Março de 1914, p. 1, col. 1; e; "Tesouro da Sè”, Gazeta de Coimbra, n. 247, 22 de Novembro de 1913, p. 2, col. 4.

${ }^{67}$ T.C., "Processos", A Província, n. . 198, Coimbra, 17 de Março de 1914, p. 1 , col. 1 .

${ }^{68}$ De facto, até a sua eleição como bispo de Coimbra não foi isenta de alguma controvérsia: o Governo Português considerava-o demasiado reaccionário e a Santa Sé temia pelo seu espírito demasiado liberal. D. Manuel Correia de Bastos 
Rocha Madahil, dispomos de um registo que sugere a sua ligação à loja maçónica conimbricense Perseverança, do Grande Oriente Lusitano, na qual Augusto Gonçalves ingressara a 9 de Janeiro de 1897. Madahil conta-nos que Eurico de Campos lhe confidenciara que "não conheceu D. M. ${ }^{\text {el }}$ Correia de Bastos Pina, mas crê poder afirmar que era maçon, e talvez até possa dizer o nome dele como irmão" ${ }^{69}$. Iniciado por Abílio Roque de Sá Barreto (1817-?) e baptizado com o pseudónimo de Fernão Vasques Gonçalves, o director do Museu Machado de Castro, que alcançaria o $3^{\circ}$ grau do rito, defenderia em 1923: "As antigas corporações maçónicas, estreitamente ligadas por si por compromissos invioláveis, lançaram-se em busca de novas formas e realizaram progressos rápidos e prodigiosos" $"$.

No seguimento do telegrama enviado por Bernardino Machado, de 20 de Fevereiro de 1914, a Comissão Central da Execução da Lei da Separação, afecta ao Ministério da Justiça, solicitava ao director, a 9 de Março, que iniciasse os estudos preparatórios para a instalação do Tesouro da Sé no templo de São João de Almedina, informando-o ainda que prosseguia o processo de afectação da igreja na Fazenda do Estado $^{71}$.

PINA, Officio do Bispo de Coimbra ao Ex. ${ }^{\text {mo }}$ Presidente do Governo Provisorio da Republica, Coimbra, Imprensa Académica, 1911, p. 4.

${ }^{69}$ Eurico de Campos soubera através de Sebastião de Almeida, genro de Sá Barreto, que este certa vez se dirigira ao "Paço Episcopal e mandou o seu cartão ao Bispo (Bastos Pina, q também era maçon); enquanto esperava q̃ o mandassem entrar, revestiu-se das insígnias maçónicas q levava num embrulho, e foi assim $\mathrm{q}^{\sim}$ apareceu ao Bispo dizendo-lhe: Nós não queremos q os jesuítas voltem $\mathrm{p}^{\mathrm{a}}$. $\mathrm{C}^{\mathrm{a}}$. O Bispo garantiu q não voltariam, e de facto assim foi. O Dr. Sebastião de Almeida garante a veracidade de tudo isto, pois lho ouviu. É genro dele".

${ }^{70} \mathrm{GHC}$, Espólio particular de António Gomes Rocha Madahil, pasta B-11, "Assuntos diversos. Actividade Política, testemunho de Eurico de Campos, documento não datado", fol. 1; A.[ntónio] GONÇALVES, Estatuária Lapidar no Museu Machado de Castro, Coimbra, Imprensa da Universidade, 1923, p. 4; e; D. Manuel Correia de Bastos PINA, [Nota Pastoral do Bispo de Coimbra], Coimbra, Typ. França Amado, 27 de Fevereiro de 1912, p. 2.

${ }^{71}$ MNMC, Correspondência recebida, Pasta 1913-1929, "Telegrama n. ${ }^{\circ} 112$ do Ministério do Fomento, 20 de Fevereiro de 1914", "Ofício n. 308 da Comissão Central da Execução da Lei da Separação do Ministério da Justiça”, 9 de Março de 1914, fol. 1; e; "Ofício n. 316 do Ministério do Fomento, 14 de Março de 1914", fol. 1 . 
O "valioso Thesouro da Sé, preciosa riquesa da mais bela arte sacra" 72 nacional, encontrava-se exposto no museu erigido nas dependências anexas à igreja catedralícia desde 1884, no seguimento da Exposição Retrospectiva de Arte Ornamental Portugueza e Hespanhola de $1882^{73}$. Estabelecido o Museu de Arte Sacra da Sé de Coimbra, o prelado continuaria a recolher os melhores espécimes das casas de religiosas conforme iam sendo encerradas com a morte da última freira ${ }^{74}$. Como notável mecenas e protector das Artes, o bispo manteve desde as últimas décadas de Oitocentos, uma luta constante com a Inspecção Geral da Fazenda para que essas peças permanecessem em Coimbra, num período que denunciava já os ventos de agitação política, como se depreende num artigo publicado no jornal A Ordem: "Toda a influencia que se tirar aos bispos sobre as coisas que pertencem ao estado é útil para o progresso dos principios modernos" 75 .

Entretanto, a 13 de Março de 1914, o padre José dos Santos Maurício, juiz da Irmandade dos Clérigos Pobres, responsável pela administração da igreja de São João de Almedina desde meados da segunda metade do século XIX, foi notificado pela administração concelhia a proceder

${ }^{72}$ MNMC, Correspondência recebida, Pasta 1913-1929, "Ofício n. 308 da Comissão Central da Execução da Lei da Separação do Ministério da Justiça”, 9 de Março de 1914, fol. 1.

${ }^{73}$ Augusto Filipe SIMÕES, "Memorias postumas", Escriptos diversos de Augusto Filippe Simões, Coimbra, Imprensa da Universidade, 1888, p. 330; e; "Ainda a Exposição Ornamental", $O$ Conimbricense, n. ${ }^{\circ}$ 3547, Coimbra, 9 de Agosto de 1881, p. 3, col. 1.

${ }^{74}$ Joaquim Martins de CARVALHO, "Arte Ornamental”, O Conimbricense, n. 3553 , Coimbra, 30 de Agosto de 1881, p. 3, col. 1; "Exposição", O Conimbricense, n. ${ }^{\circ}$ 3710, Coimbra, 6 de Março de 1883, p. 3, col. 3; D. Manuel Correia de Bastos PINA, Officio do Bispo de Coimbra ao Ex. ${ }^{\text {mo }}$ Presidente do Governo Provisorio da Republica acerca do Thesoiro da Sé da mesma cidade, Coimbra, Imprensa Académica, 1911, p. 4; e; Carlos SERRA, D. Manuel Correia de Bastos Pina: paladino do património, Coimbra, Seminário do Mestrado em Museologia e Património Cultural, FLUC, 1999, pp. 6-8.

${ }^{75}$ D. Manuel PINA, A execução das leis de Fazenda na extincção dos Conventos. Queixa a Sua Majestade El-Rei do que se fez na extincção do de Semide em Agosto de 1896, Lisboa, M. Gomes, 1896, pp. 65-66; e; Carlos SERRA, D. Manuel Correia de Bastos Pina: paladino do património, [...], p. 11 . 
à entrega do imóvel para alargamento das áreas expositivas do Museu Machado de Castro, o que recusaria veementemente ${ }^{76}$.

Perante a afronta, um grupo de estudantes universitários católicos do Centro Académico de Democracia Cristã, do qual faziam parte Manuel Gonçalves Cerejeira e António de Oliveira Salazar, decidira publicar um folheto exortando para a realização de uma manifestação pública no Largo da Sé no dia 15 de Março. Dirigido a todos os Católicos, o panfleto reunia uma vasta lista de críticas acerca da perseguição dirigida ao povo, "Está mais uma vez em jogo a liberdade das nossas crenças", e da política nacional de usurpação dos edifícios cultuais, "a propriedade dos nossos Templos". Exigindo o fim das espoliações, os estudantes temiam que a igreja "fosse musealizada para satisfação de doentias vaidades artísticas com que se acobertam inconfessaveis sectarimos" $" 77$.

Este documento mostra, resumidamente, as acções perpetradas durante os primeiros anos da República na cidade Coimbra. Salientando o encerramento de seis igrejas na cidade, questionavam a solução tomada em "inutilisar um templo transformando-o em armazem ou casa-forte, quando nos países cultos, como a França, é em nome da arte que está reclamando a conservação das mais humildes capelinhas com o seu culto próprio?!". No final do apelo exigiam entusiasticamente: "Basta de expoliações! Os templos dos católicos são para os católicos!"78.

Ignorando os acontecimentos e procurando agradecer toda a cooperação disponibilizada na patriótica obra de educação nacional, Gonçalves pressionava então o ministro da Instrução Pública e o director das Obras Públicas de Coimbra para a cedência do Tesouro da Sé e da igreja de São João de Almedina, "contigua paredes meias, ao paço episcopal, onde se acha instalado o Museu Machado de Castro, e

76 "S. João de Almedina", A Humanidade, 29 de Março de 1914, p. 1, col. 2; e; MNMC, Correspondência recebida, "Ofício n. 322 da Direcção das Obras Públicas, 18 de Março de 1914”, fol. 1.

${ }^{77}$ [Folheto] Aos Católicos de Coimbra, Coimbra, Tip. da Gazeta de Coimbra, 14 de Março de 1914.

${ }^{78}$ [Folheto] Aos Católicos de Coimbra, Coimbra, Tip. da Gazeta de Coimbra, 14 de Março de 1914. 
que verdadeiramente lhe pertence" 79 . Na verdade, esta não só integrava o palácio dos bispos de Coimbra, como the servia de capela privativa.

Obviamente que a reacção republicana não se faria esperar e logo no dia 15, um grupo de liberais saía em sua defesa: "O sr. Antonio Augusto Gonçalves, apoiado por todos os bons conimbricenses, tanto artistas como liberaes, solicitava que the fosse concedida a igreja de S. João d'Almedina [teatro dos snobismos monárquico e jesuíticos] para a expansão do Museu Machado de Castro, museu que é um dos motivos d'orgulho desta cidade, expansão indispensavel para lá se instalar o museu de arte religiosa mal acondicionado nas dependencias da Sé" 80 .

Abalada a ordem pública por este golpe provocador, os republicanos apelavam então para uma contra-manifestação, à mesma hora e lugar, para defrontar os catoliqueiros $^{81}$. O próprio Gonçalves, mostrava mais tarde, a sua indignação quando ouvira que "a República expulsava os fieis da casa de Deus" ${ }^{\prime 2}$.

A polémica, continuamente explorada pela imprensa local, contou ainda com um segundo folheto da autoria de António de Oliveira Salazar, assinado com o pseudónimo de Alves da Silva - São João de Almedina ao Snr. Ministro da Justiça -, no qual comprovava, com base no próprio diploma de lei de 20 de Abril de 1911, a ilegalidade da incorporação da igreja no Museu Machado de Castro. As deslumbrantes solenidades religiosas aí celebradas, escreve Salazar, afligiam dolorosamente "os olhos doentes dos maçonicos de Coimbra" "83. Curiosamente, no discurso publicado no jornal A República, a 19 de Janeiro de 1949,

${ }^{79}$ MNMC, Copiador I, António GONÇALVES, "Comunicados enviados ao Ministro da Instrução Pública e ao Director das Obras Públicas de Coimbra”, 15 de Março de 1914, fols. 21, v; 23.

${ }^{80}$ ZEBEDEU, "Banalidades", O Debate, n. ${ }^{\circ}$ 159, 26 de Setembro de 1915, p. 2; e; [Folheto] Povo Liberal Álérta!, Coimbra, Typ. Vianna, 15 de Março de 1914.

${ }^{81}$ [Folheto] Povo Liberal Álérta!, Coimbra, Typ. Vianna, 15 de Março de 1914; e; T.C. “A igreja de S. João de Almedina”, A Província, n. . 213, Coimbra, 8 de Maio de 1914, p. 1, col. 1.

${ }^{82}$ ZEBEDEU [Augusto GONÇALVES, "Banalidades", O Debate, n. ${ }^{\circ}$ 159, 26 de Setembro de 1915, Coimbra, p. 1, col. 4.

${ }^{83}$ Alves da SILVA, São João de Almedina ao Snr. Ministro da Justiça, Porto, Associação Católica do Porto, [1914], pp. 1 e 2; e; "S. João de Almedina. Questão aberta", A Humanidade, 29 de Março de 1914, p. 1, col. 2. 
ao tratar do direito à manifestação pública, o Presidente do Conselho recordava o episódio que ocorrera trinta e cinco anos antes no Largo da Feira dos Estudantes em Coimbra!!

Mas com o roubo ocorrido no Museu das Pratas da Sé, na noite de 21 de Junho de $1914^{84}$, e o perigo eminente das obras decorrentes nos pisos superiores das respectivas salas, afectas ao museu de Zoologia da Universidade de Coimbra ${ }^{85}$, o processo iria definitivamente avançar. Apoiado pelo ministro Manuel Joaquim Rodrigues Monteiro (1879-1952), "spirito cultissimo" da arqueologia e da crítica de arte, conseguira-se assim comprovar a insegurança das instalações e exigir a deslocação do acervo para a igreja anexa, o que só viria a acontecer seis anos depois, em Julho de $1920^{86}$.

Ainda em 24 de Março de 1914, era publicado no jornal A Província um artigo no qual era salientado que a empresa cultural de Augusto Gonçalves não deveria ser tão enaltecida como o próprio pretendia, uma vez que o Governo já tentara afastá-lo da direcção da Escola de Desenho Industrial Brotero, recusara a incorporação de obras proveniente do Palácio Episcopal de Castelo Branco e reduzira, em cem réis, o já magro orçamento do Museu Machado de Castro ${ }^{87}$.

Não obstante da suposta necessidade da transferência do espólio de um edifício para o outro, ambos ligados pelo setecentista Arco do Bispo, o reitor Guilherme Alves Moreira (1861-1922), em 22 de Agosto de 1914, demonstrava o interesse da Universidade nesta deslocação mas não sem antes procurar comprovar que obras em curso

\footnotetext{
${ }^{84}$ MNMC, Copiador I, António GONÇALVES, "Comunicado enviado ao Comissário da Polícia de Coimbra”, 22 de Junho de 1914, fol. 27.

${ }^{85}$ MNMC, Correspondência recebida, "Ofício n. 296 do reitor António Luís Gomes", 22 de Agosto de 1914.

${ }^{86}$ MNMC, Copiador I, António GONÇALVES, "Comunicado enviado ao Comissário da Polícia de Coimbra", 22 de Junho de 1914, fol. 27 e v.; Copiador I, António GONÇALVES, "Ofício n. ${ }^{\circ} 118$ enviado ao Presidente da Direcção da Sociedade de Defesa e Propaganda de Coimbra", 4 de Abril de 1921, fol. 81; e; "Ofício n. ${ }^{\circ} 117$ enviado ao Reitor da Universidade de Coimbra", 30 de Abril de 1921, fol. 80.

${ }^{87}$ T.C., "Longe de ilusões", A Província, Coimbra, 24 de Março de 1914, p. 1, cols. 2 e 3; António GONÇALVES, Monitoria dirigida aos Srs. Ministros [...] pp. 4 e 5; MNMC, Copiador I, António GONÇALVES, "Ofício n. . 119 enviado ao Reitor da Universidade de Coimbra", 10 de Abril de 1921, fol. 81; e; "Comunicado enviado ao Governador Civil”, de 14 de Outubro de 1914, fol. 32.
} 
não prejudicavam as colecções artísticas depositadas no Museu da Sé. Além do mais, demonstrou notoriamente o apoio incondicional na grandiosa obra do Museu Machado de Castro, que "corresponderá sempre da parte desta Universidade uma cooperação tanto quanto possível eficaz", colaboração confirmada pela atribuição de um subsídio pecuniário e no depósito de algumas peças de arte. Manifestaria ainda o seu compromisso "em pugnar para que se faça essa transferência, tanto mais quanto é certo que a adaptação da parte do edificio do Museu cedida para a Zoologia exige que seja demolida a denominada sala da palmeira, que aliaz está prejudicando sensivelmente o edifício"\$8.

A outorga definitiva da igreja acabaria por acontecer em 10 de Dezembro de 1914, na presença das entidades envolvidas no processo, assentando no respectivo auto de entrega os bens que seriam incorporados e os que pertencentes à Irmandade dos Clérigos Pobres ficariam em depósito na instituição museológica ${ }^{89}$.

Continuando com esforço e tenacidade a trabalhar na promoção das instalações, nomeadamente as da igreja, que necessitavam de "profundas alterações para poder ter vantagem em servir para Museu onde deverão ser arrecadados objectos de arte sacra de grande valor" ${ }^{\prime 90}$, o director decidira reaproveitar diversos artefactos históricos, provenientes de diferentes monumentos da cidade. Entre eles, o portal da igreja do Convento de Santa Ana, os azulejos hispano-árabes da Sé Velha e os painéis seiscentistas Misericórdia para o revestimento de diversas paredes, ou as lisonjas da sala capitular da concatedral para o pavimento das antigas cocheiras ${ }^{91}$.

${ }^{88}$ MNMC, Correspondência recebida, "Ofício n. ${ }^{\circ} 296$ da Reitoria”, 22 de Agosto de 1914.

${ }^{89}$ MNMC, Copiador I, Correspondência recebida, Humberto de Carvalho, "Cópia do auto de entrega da igreja de São João de Almedina”, 12 de Dezembro de 1914, fol. 1 .

${ }^{90}$ DGEMN, Museu Nacional Machado de Castro, "Memória descritiva do Projecto de adaptação da Egreja de S. João d'Almedina para Museu de arte sacra”, 30 de Março de 1914, p. 1.

${ }^{91}$ MNMC, Copiador I, António GONÇALVES, "Comunicado enviado ao Provedor e à Mesa da Misericórdia”, 4 de Novembro de 1913, fol. 19, v; "Comunicado enviado ao Reitor da Universidade de Coimbra", 9 de Dezembro de 1913, fol. 20, v; e; "Ofício n. ${ }^{\circ} 39$ enviado Director de Obras Públicas de Coimbra", 6 de Fevereiro de 1917, fol. 52, v. 
Até à inauguração da secção de ourivesaria, tecidos e bordados antigos do Museu, somente ocorrida a 10 de Julho de 1923, as obras decorreram a um ritmo demorado, mesmo quando se pressionara vários ministros, "que se teêm mostrado insensíveis e surdos aos clamores e reclamações", pela atribuição das verbas necessárias temendo pela falta de segurança das instalações ${ }^{92}$.

Este atraso causou grandes embaraços a Gonçalves, que humilhado e desautorizado, dirigiu duras críticas à inoperância do Estado e denunciou a anarquia dos serviços públicos: "A defesa e reparação dos monumentos de arte foram ultimamente entregues à superintendência autoritária das repartições de engenharia, condutores e subalternos, sob a alçada do Ministério do Comércio e das estradas!"... pelo que recorrer ao Estado seria, uma vez mais, escusado ${ }^{93}$.

Cansado e desapontado com o rumo do projecto que lhe ocupara os últimos vintes anos da sua vida, António Augusto Gonçalves, "assim, esquecido, no completo abandono de todos os dias [...] pungido em desenganos de decepção, de despeito e de remorsos" $"$, abandonaria a direcção do Museu Machado de Castro em Novembro de 1929, não sem antes ser afrontado, novamente, com a nomeação de Vergílio Correia Pinto da Fonseca (1888-1944) para o seu antigo cargo, quando planeara a ascensão do seu amigo e colaborador, o arquitecto Augusto Silva Pinto ${ }^{95}$.

${ }^{92}$ MNMC, Copiador I, António GONÇALVES, “Ofício n. 53 enviado ao Governador Civil de Coimbra", 12 de Junho de 1923, fols. 97 e 98; Gazeta de Coimbra , n. ${ }^{\circ}$ 128, p. 1, col. 6; António GONÇALVES, Monitoria dirigida aos Srs. Ministros [...] p. 4; e; Copiador II, António GONÇALVES, "Ofício n. 207 enviado Comissário da Polícia de Coimbra", 27 de Janeiro de 1928, fol. 21; Copiador I, António GONÇALVES, "Ofício n. ${ }^{\circ} 72$ enviado ao Presidente do Conselho de Arte e Arqueologia", 18 de Outubro de 1923, fol. 101; "Museu d'Arte Sacra em Coimbra", Diário de Notícias, 2 de Fevereiro de 1920, p. 1, cols. 2-3; e; "Coimbra-a-morta", Diário de Notícias, 30 de Abril de 1920 , p. 2.

${ }^{93}$ MNMC, Copiador I, António GONÇALVES, “Telegrama enviado ao Ministro do Fomento", 7 de Junho de 1915, fol. 38; e; "Comunicado enviado a Augusto de Castro", 13 de Maio de 1920, fol. 93 e v.

${ }_{94}^{4}$ A. GONÇALVES, Enumeração das obras preparativas, [...], p. 4.

${ }^{95}$ Lourenço de ALMEIDA, "Subsídios para a História do Museu Machado de Castro”, Ocidente, vol. XXXI, Lisboa, 1947, pp. 70 a 72. 
Profundamente imbuídos nos valores ideológicos do novo regime, os mecanismos adoptados para alcançar os objectivos delineados na reestruturação das unidades museológicas, quer das existentes, quer das que seriam estabelecidas de raiz, determinariam o sacrifício de uma boa fracção do património milenar da Igreja Católica em prol da democratização cultural e educação nacional. Com o encerramento de vários edifícios cultuais, sendo o caso da igreja de São João de Almedina o mais polémico, seria inevitável a nacionalização dos seus objectos devocionais e alfaias litúrgicas.

A política cultural e a cultura museológica encetadas em Coimbra nos anos subsequentes à implantação da República acabariam, não de forma inocente, por se centralizar, quase exclusivamente, em torno da grande obra institucional do Museu Machado de Castro. Disso é prova a inércia a que foi votado o projecto do Museu de Arte de Sacra previsto para a capela universitária de São Miguel - tardiamente efectivado pois só foi inaugurado em Dezembro de 1972 -, o que manifesta o interesse do governo em encerrar o templo à comunidade académica, e da estratégica confluência do espólio artístico de diversas instituições culturais locais numa só, destacando-se as colecções do Museu de Antiguidades do Instituto de Coimbra e do Museu de Arte Sacra da Sé.

De acordo com pensamento de António Augusto Gonçalves, ao serem reunidos os principais acervos artísticos de Coimbra e sua região num único monumento apto para as receber - o antigo Paço Episcopal, agora transformado em templo das musas -, era então possível dar início ao "grande plano da educação geral e da regeneração e valorização do trabalho na vida portuguesa" ${ }^{6}$ junto das classes mais desfavorecidas.

Colaborando afincadamente na elaboração dos principais diplomas de preservação e divulgação dos acervos históricos e artísticos da Nação, porque beneficiando das estreitas relações estabelecidas com diversos ministros, como sugere a avultada documentação epistolar trocada com António José de Almeida, Bernardino Machado, Macieira Júnior, Silvestre Falcão ou Manuel Monteiro, entre os principais, Gonçalves

${ }^{96}$ António GONÇALVES, Ao Governo da Republica, [...], p. 1. 
conseguira num curto hiato cronológico lançar as sólidas fundações daquele que é hoje um dos principais museus nacionais ${ }^{97}$.

Apesar de todas as decepções e batalhas burocráticas travadas, Gonçalves era no entanto reconhecidamente enaltecido como um dos grandes propulsores dos ideais políticos do regime republicano na principal cidade erguida à beira do Mondego. Já desde a sua juventude manifestara um espírito "tanto ou quanto irrequieto e independente no campo das ideias politicas e religiosas" mas "sempre tenaz no apostolado da instrução artística popular"98, o que contribuiria para que assim vigorasse a ideia de que o novo governo democratizara a cultura e dedicara mais atenção às questões do património monumental do que durante o elitista período da Monarquia.

Entre os muitos elogios que lhe foram dirigidos, ainda em vida, concluamos recorrendo aos excertos retirados de dois artigos redigidos num jornal da época por Joaquim Martins Teixeira de Carvalho (1861-1921): "Se como republicano são valiosos os serviços, como amigo da arte na sua expressão de educadora dos povos como êle a tomou sempre, bem póde dizer-se que são muitíssimas" as suas qualidades como director ${ }^{99}$, pois se houve obra manifestamente republicana em Coimbra, esta fora na verdade, a do Museu Machado de Castro ${ }^{100 .}$

Afinal de contas, a res publica era a coisa do povo...

${ }^{97}$ Gonçalves conseguira num período recorde de três anos nacionalizar o paço episcopal de Coimbra e reunir o espólio dos museus existentes ou entretanto extintos na cidade. Sobre o processo de estabelecimento e evolução de outros museus nacionais em palácios episcopais durante este período vide Milton PACHECO, "(Es)Paços para a República: A musealização dos paços episcopais e a democratização cultural em Portugal durante a I República”, I República e Republicanismo. Congresso Histórico Internacional, Assembleia da República.

98 "GONÇALVES, António Augusto", Grande Enciclopédia Portuguesa e Brasileira, [...] p. 552, col. a.

99 “O Museu Machado de Castro", A Província, n. ${ }^{\circ} 43$, Coimbra, 3 de Setembro de 1912, p. 1, col. 4.

100 T.C.“A igreja de S. João de Almedina”, A Província, n. 213, Coimbra, 8 de Maio de 1914, p. 1, col. 2. 


\section{Bibliografia}

Fontes manuscritas e dactilografada

Arquivo Central do Paço Episcopal de Coimbra: Correspondência do Bispado de Coimbra

Arquivo Histórico Municipal de Coimbra: Actas das Sessões da Câmara Municipal de Coimbra

Arquivo do Ministério da Educação: Correspondência expedida e recebida do Conselho de Arte e Arqueologia da Segunda Circunscrição

Arquivo da Universidade de Coimbra: Mitra Episcopal de Coimbra e Faculdade de Letras da Universidade de Coimbra

Direcção Geral dos Edifícios e Monumentos Nacionais / Instituto de Habitação e Reabilitação Urbana: Paço Episcopal de Coimbral Museu Machado de Castro/ Igreja de São João d'Almedina

Gabinete Histórico da Cidade de Coimbra: Espólio particular de António Augusto Gonçalves e António Gomes da Rocha Madahil

Museu Nacional de Machado de Castro: Correspondência recebida e expedida

\section{Imprensa local e nacional}

Debate, $O$ (Coimbra); Despertar, $O$ (Coimbra); Diário de Coimbra; Diário de Lisboa; Diário de Notícias; Gazeta de Coimbra; Imparcial, O (Coimbra); Lucerna, A (Coimbra); Notícias de Coimbra; Província, A; Resistência.

\section{Obras de consulta}

António Augusto Gonçalves. Homenagem do «Instituto de Coimbra», O Instituto, volume CVIII, Coimbra, Coimbra Editora, Limitada, 1946.

AZEVEDO, Carlos Moreira (direcção de), História Religiosa de Portugal, Rio de Mouro, Círculo de Leitores, 2000.

BANDEIRA, Ana Maria, MENDES, Marta Gama e SILVA, Ana Margarida Dias da, "Mitra Episcopal de Coimbra: descrição arquivística e inventário do fundo documental", Boletim do Arquivo da Universidade de Coimbra, volumes XXIII e XXIV, Coimbra, Arquivo da Universidade de Coimbra, 2003-2004/2005-2007, 2007, pp. 87 a 137. 
CARVALHO, Alberto Martins de, A Lei da Separação, Coimbra, Tipografia Popular, 1917.

CARVALHO, Rui Francisco da Silva Paiva de, O reflexo da Lei da Separação na imprensa coimbrã (1911-1926), Coimbra, trabalho de investigação realizado no âmbito do Seminário de História Institucional e Política no Mestrado em História Contemporânea, 1996.

CASTRO, Eugénio de e GONÇALVES, António Augusto, Noticia histórica e descriptiva dos principaes objectos de ourivesaria existentes no Thesoiro da Sé de Coimbra, Coimbra, Imprensa Académica, 1911.

CATROGA, Fernando, O republicanismo em Portugal. Da formação ao 5 de Outubro de 1910, Lisboa, Notícias Editorial, 1999.

CATROGA, Fernando, e ALMEIDA, Pedro Tavares, Res Publica. Cidadania e representação política em Portugal [catálogo da exposição], Lisboa, Assembleia da República, 2010.

CATROGA, Fernando, "O laicismo e a questão religiosa em Portugal (1865-1911)”, Análise Social, volume 100, 1988, Lisboa, pp. 211 a 273.

CEREJEIRA, D. Manuel Gonçalves, Vinte anos de Coimbra, Lisboa, Edições Gama, 1943.

COELHO, Domingos Pinto, A Separação. Decreto com força de lei de 20 de Abril de 1911. As Reclamações dos Catholicos, Lisboa, Typographia da Papelaria Progresso, 1913.

COSTA, Afonso, Discursos parlamentares (1911-1914), MARQUES, A.H. de Oliveira (Compilação, prefácio e notas), Amadora, Livraria Bertrand, 1976.

CRUZ, Manuel Braga da, As Origens da Democracia Cristã e o Salazarismo, Lisboa, Editorial Presença/Gabinete de Investigações Sociais, 1980.

A Faculdade de Letras da Universidade de Coimbra ao País, Coimbra, Tip. França Amado, 1919.

FERNANDES, António Teixeira, Igreja e sociedade na Monarquia Constitucional e na Primeira República, Porto, Estratégias Criativas, 2007.

"GONÇALVES, António Augusto", Grande Enciclopédia Portuguesa e Brasileira, volume XII, Lisboa/Rio de Janeiro, Editorial Enciclopédia, Limitada, s.d., pp. 551-553. 
GONÇALVES, António Augusto, Depoimento para ajuntar ao volumoso processo dos malfeitores da Arte em Portugal. Por uma testemunha que não tem amisade nem parentesco com os réus, Coimbra, Minerva Central, 1912.

GONÇALVES, António Augusto, Enumeração para as obras preparativas para a instalação do Museu Machado de Castro, Coimbra, Tipografia “O Despertar”, 1929.

GONÇALVES, António Augusto, Ao Governo da Republica, Coimbra, s.e., 30 de Dezembro de 1910.

GONÇALVES, António Augusto, Monitoria dirigida aos Srs. Ministros, Deputados e Senadores, ou quem suas veses fisér, Acêrca do Museu Machado de Castro de Coimbra, Coimbra,Tip. d'O Despertar, 1921. [GONÇALVES, António Augusto], Museu de Antiguidades do Instituto de Coimbra. Notas, Coimbra, Typ. Auxiliar d'Escriptorio, 1911.

GOUVEIA, Henrique Coutinho, Museus de Coimbra. Da I Exposição Distrital à organização do Museu Machado de Castro, Coimbra, Coimbra Editora, 1980.

MOURA, Maria Lúcia de Brito, A Guerra Religiosa na I República, Cruz Quebrada, Notícias Editorial, 2004.

NETO, Vítor, O Estado, a Igreja, e a Sociedade em Portugal (1832-1911), Lisboa, Imprensa Nacional - Casa da Moeda, 1998.

NETO, Vítor, "Estado, Igreja e Anticlericalismo na $1^{\text {a }}$ República", Actas do Colóquio O Anticlericalismo Português: História e Discurso, Aveiro, Centro de Línguas e Culturas/Departamento de Línguas e Culturas da Universidade de Aveiro, 2002, pp. 31 a 50.

NUNES, João Paulo Avelãs, A História Económica e Social na Faculdade de Letras da Universidade de Coimbra (1911-1974). Ascensão e queda de um paradigma historiográfico, Coimbra, Dissertação de Mestrado em História Contemporânea de Portugal apresentada à Faculdade de Letras da Universidade de Coimbra, 1993. [policopiada]

PACHECO, Milton Pedro Dias, "Deus, Pátria e Restauro: A acção da Direcção Geral dos Edifícios e Monumentos Nacionais na salvaguarda dos monumentos religiosos de Amarante", Actas do II Congresso Histórico de Amarante, Amarante, Câmara Municipal de Amarante, 2009.

PACHECO, Milton Pedro Dias, “(Es)Paços para a República: A musealização dos paços episcopais e a democratização cultural em 
Portugal durante a I República", Actas do Congresso Histórico Internacional: I República e Republicanismo, Lisboa, Assembleia da República [no prelo].

PACHECO, Milton Pedro Dias, Por detrás de um Museu. O Paço Episcopal de Coimbra: história e memória, dissertação de Mestrado em História da Arte, especialidade em História da Arte, apresentada à Faculdade de Letras da Universidade de Coimbra, Faculdade de Letras da Universidade de Coimbra, 2009. [policopiada]

PINA, Dom Manuel Correia de Bastos, Alocução enviada ao Clero da Diocese de Coimbra, Coimbra, Typ. França Amado, 20 de Novembro de 1912.

PINA, Dom Manuel Correia de Bastos, [Nota Pastoral do Bispo de Coimbra], Coimbra, Typ. França Amado, 27 de Fevereiro de 1912. PINA, Dom Manuel Correia de Bastos, Officio do Bispo de Coimbra ao Ex ${ }^{m o}$ Presidente do Governo Provisorio da Republica acerca do Thesoiro da Sé da mesma cidade, Coimbra, Imprensa Académica, 1911.

Povo Liberal Álérta, Coimbra, Typ. Vianna, 15 de Março de 1914.

Protesto collectivo dos Bispos Portuguezes contra o Decreto de 20 d'abril de 1911, que separa o Estado da Egreja, s.l., s.e., 6 de Maio de 1911.

RAMOS, António de Jesus, “A Igreja e a I República - A reacção católica em Portugal às leis persecutórias de 1910-1911”, Didaskalia, Lisboa, volume XIII, 1983, pp. 255 a 302.

RODRIGUES, Manuel Augusto (Direcção de), Memoria Professorum Vniversitatis Conimbrigensis (1772-1937), Coimbra, Arquivo da Universidade de Coimbra, 1992.

ROQUE, Maria Isabel Rocha, Musealização do Sagrado. Práticas museológicas em torno de objectos do culto católico, Lisboa, Dissertação para obtenção do Grau de Doutor pela Universidade Lusíada de Lisboa, 2005.

SEABRA, João Maria, A lei portuguesa da separação do Estado das Igrejas de 20 de Abril de 1911, Lisboa, Centro Cultural de Lisboa Pedro Hispano, 2008.

SEABRA, João, O Estado e a Igreja em Portugal no inicio do século XX, Cascais, Princípia, 2009.

SERRA, Carlos, António Augusto Gonçalves: a educação e o museu, Coimbra, Seminário de Museus: Investigação e Ensino, no âmbito 
do Mestrado em Museologia e Património Cultural, apresentado à FLUC, 1999. [policopiada]

SERRA, Carlos, António Augusto Gonçalves. O percurso museológico, Coimbra, Dissertação de Mestrado em Museologia e Património Cultural apresentada à Faculdade de Letras da Universidade de Coimbra, 2002.

SERRA, Carlos, D. Manuel Correia de Bastos Pina: paladino do património, Coimbra, Seminário do Mestrado em Museologia e Património Cultural, apresentado à FLUC, 1999.

SERRA, Carlos, Em torno do Museu de Arte Sacra da Universidade de Coimbra, Coimbra, Seminário do Mestrado em Museologia e Património Cultural, apresentado à FLUC, 1999.

SILVA, Alves da, São João de Almedina ao Snr. Ministro da Justiça, Porto, Associação Católica do Porto, [1914?].

VASCONCELOS, António de, Real Capela da Universidade, Coimbra, Arquivo da Universidade de Coimbra/Livraria Minerva, 1990. 